\title{
Adapting Chinese Buddhism to Religious Life in Contemporary Germany: Challenges and Opportunities in the Twenty-first Century
}

\author{
CARSTEN KRAUSE \\ Numata Center for Buddhist Studies, University of Hamburg
}

Keywords: Transmission, contemporary, Chinese Buddhism, Germany, image, expectations, adaptation

DOI: https://dx.doi.org/10.15239/hijbs.01.01.11

Abstract: While Buddhist traditions from China have attracted European scholars since the early nineteenth century, Chinese Buddhist practices have not influenced religious life in Europe outside of academic studies. This paper explores why Chinese Buddhism has not resonated in Europe to the same extent as Japanese, Tibetan and Southeast Asian Buddhism. This analysis looks to Germany as one of the biggest European countries with a long history of Buddhism. First, it considers existing institutional structures of Buddhism in Germany. Secondly, it examines the images of Chinese Buddhism within the context of soteriological expectations in German society. Thirdly, it reflects on the context of institutional Buddhism in China and its influence on the transmission of Chinese Buddhism to Germany. Based on these analyses, this paper shows that Chinese Buddhism faced various challenges during its transmission into European society. Despite these challenges, the widely admired traditions, contemporary pluralistic dynamics, and openness to international adaptability also creates growing potential for Chinese Buddhism's acceptance in Europe. 


\section{Buddhism in Europe and the Attractiveness of Chinese Buddhism}

s demonstrated by many previous works, Buddhism found its
way to Europe through a complicated process spanning more
than two hundred years. This long process led to a heterogeneous
development all over Europe. ${ }^{1}$ In order to get deeper insight into the
role of Chinese Buddhism, I would like to focus on its situation in
Germany, as one of the biggest European countries with a long histo-
ry of Buddhist life.

Europeans developed a more serious interest in Buddhism over the course of the nineteenth century. However, this interest was mainly dominated by an intellectual approach, which led to a search for Buddhist texts written in the original, ancient languages of Sanskrit and Pali. When Germans started traveling to Asia at the beginning of the twentieth century with the explicit purpose of developing direct contact with Buddhist practitioners, many of them were still focused on Buddhist traditions in South East Asia. It was not until much later that Buddhist representatives themselves travelled from Asia to Europe and began attracting more attention to this foreign religion. The active movement of Buddhists from Asia to Europe became a turning point because it involved more and more people from East Asian countries where Buddhism is thriving beyond practices in the Buddha's homeland itself.

The growing influence of Buddhists from Asian countries in Germany became more significant after World War II (which is comparable with the situation in many other European countries). In the 1950s and 1960s, the broader interest in Buddhist practice among Germans was dominated by Japanese (Zen) Buddhism. Beginning in the 1970s, Tibetan Buddhism became increasingly attractive in Germany. Both of these traditions are still the most

1 For a comprehensive overview of second literature about the transmission of Buddhism to Europe, which provides the background and, of course, much more detail with regard to the following introductory remarks, see: Baumann, Deutsche Buddhisten; Baumann, 'Buddhism in Europe'; Baumann, 'Global Buddhism'. 
popular ones in Germany today. Although they were highly valued, especially among German intellectuals, some other Asian traditions, like that from Vietnam (mainly transmitted by the so called 'Vietnamese boat people'), found their way into Europe, but remain only as a cultural aspect of Asian diaspora and are hardly noticed by the German public.

In contrast to the development described above, in addition to the broader search for authentic Buddhist life in Asia, other circumstances, both internationally and within Germany, paved the way to a Western style of Buddhism. In general, these circumstances can be understood through two patterns that shaped the current situation of Buddhism in Germany: the ability for international movement of Buddhism and the cultural context of Germany.

Buddhist traditions from Asia that became especially attractive to Germans were transmitted either through masters who came directly from Asia or through European masters who were trained by local masters in Asia and then returned to Europe to teach. In both cases, the religious authorization from master to disciple, according to Asian Buddhist conventions, played a growing role, as well as the individual charisma of the teachers and the political and economic circumstances of the time. This new approach contrasted the previous European interest, which primarily relied on research by intellectuals.

In the light of those criteria, it is understandable how the traditions from Japan and Tibet became so well-known and popular in Germany up to the present time. In Japan, Buddhism developed into a vivid and broadly accepted religion while undergoing several adaptations to modern social life during early stages. It was also made more easily spread to Westerners through the influential works of D. T. Suzuki (1870-1966). The political circumstances after World War II allowed this view of Japanese Buddhism to easily spread to foreign countries. Meanwhile, economic development in Japan promoted international exchange and provided Buddhist foundations with resources to invest abroad.

Though still political in nature, Tibetan Buddhism spread internationally for other reasons. A large numbers of Tibetans, including high ranking masters, were dispersed in various places around the 
world since the 1950s. This circulation of Tibetans, coupled with the growing media hype surrounding Tibet in general, led to the early stages of Tibetan Buddhism's international adaptations.

On the other hand, Chinese Buddhists were much more focused on their personal fate within China. Buddhist masters from Mainland China who fled under political pressure primarily settled down in Hong Kong, Taiwan, or the United States and immersed themselves in Chinese speaking communities. This did not lead to the same internationalization as Buddhism from Japan and Tibet. Various circumstances led to the strong decline of Chinese Buddhism-at least within China-until the end of the Cultural Revolution. Even after religious revival that began in the 1980s, Chinese Buddhism was still constrained by many domestic challenges. Chinese Buddhists not only had to regain political and social acceptance, but also needed economic strength in order to rebuild their monasteries within China. These internal challenges prevented Chinese Buddhism from spreading to Europe during the same time as Buddhism from Japan and Tibet.

Apart from the primary influence of Buddhism from Japan and Tibet based on political and economic factors, the cultural context of Germany also played a role in the adaptation of Buddhism. Although this originated from language and cultural barriers, Buddhism within Germany developed into a Western Buddhist way of life with local characteristics. These include a lack of fulfilment of rules and rituals, as well as more active transformations concerning attitudes toward gender and political and social engagement. The cultural context caused a selective acceptance of existing (Asian) Buddhist traditions and created a hybrid mixture of mainly non-Buddhist attitudes, integrating only a few aspects of Buddhism as part of a contemporary life style. ${ }^{2}$

2 On the questions of acceptance vs. transformation of ritual practices concerning (non-Chinese) Buddhist traditions in Germany see the research project report by Prohl, 'Projektbericht zum DFG-Projekt "Sinnsuche-Coping-Streben nach Woblgefühl”'. 


\section{Current State of Chinese Buddhism in Germany/Europe: General Image and Possible Expectations from a German Audience}

\section{II.1 Prominent Existent Chinese Buddhist Institutions in Germany}

In analysis of Chinese Buddhism in Germany on an institutional level, the most renowned centres are found in the capitol, Berlin, while some other initiatives are situated in Frankfurt or other places around the country. Much can be interpreted in light of the previously described historical developments.

\section{Fo Guang Shan Tempel Berlin}

One of the first and largest initiatives to build up Chinese Buddhist centre in Germany was the leader of Fo Guang Shan 佛光 山 (FGS). Although he was raised in Mainland China, Venerable Master Hsing Yun 星雲 (b. 1927) fled to Taiwan to keep Buddhist practice alive (similar to the Tibetan case) and later transmitted it to other countries. His transnational circumstances were dependent on political and economic factors comparable to those mentioned in the case of Japanese Buddhism mentioned before. ${ }^{3}$

Founded in 1992, the Fo Guang Shan Tempel Berlin had a long way to go to become the temple it is today, until it some years later it moved to its current location where it is now investing in a new building. From its beginning, the centre was mainly managed by Chinese native speakers and its central purpose was to address the overseas Chinese community. ${ }^{4}$ Many of the Germans attracted to this centre were challenged by both language barriers and unfa-

3 For the general context see Günzel, Die Taiwan-Erfahrung des chinesischen Sangha.

4 See the homepage of the Fo Guang Shan Tempel Berlin, which mainly exists in Chinese: http://www.fgs-tempel.de. In addition to that one may also observe a similar background of the Fo Guang Shan Tempel Frankfurt which was founded in 2004, http://www.foguangshan.de. 
miliar religious customs (even when comparing the FGS system to other non-Chinese Buddhist ones). Although the Fo Guang Shan Tempel Berlin was established more than twenty years ago, it still mainly functions as an address for Chinese living overseas.

What makes the FGS system special and sometimes even leads to irritation among Germans, as well as other Europeans, is that it does not exclusively align itself with traditional, well-known Chinese Buddhist schools, such as Chan or Pure Land. Rather, FGS represents a twentieth century modernization movement by combining different Buddhist traditions, adding contemporary content and producing its own brand of a so-called 'Humanistic Buddhism' (Renjian Fojiao 人間佛教) based on reform movements from the twentieth century. ${ }^{5}$ As evident from its experience in other German cities, the establishment of additional Fo Guang Shan temples failed when the local Chinese community did not give enough support. The German population, on the other hand, was hardly involved at that stage.

Based on this development, similar to the case of the Vietnamese diaspora, one of the main challenges FGS faces is attracting the German target group. The FGS organizes activities in the German language, provides useful existing and forthcoming translation work, and is planning for a new modern building to replace the temple site. Yet as of now, Germans only represent a minority within the temple and have not been sensitized to Buddhism from China in such an intensive and strategic manner. ${ }^{6}$

5 On the specialties of the Fo Guang brand see for example, Günzel, Die Taiwan-Erfabrung des chinesischen Sangha; Chandler, Establishing a Pure Land on Earth. With regard to the challenges and opportunities for a certain acceptance of Renjian Fojiao (in its broad sense) in Europe see Travagnin, 'Genealogy and Taxonomy'.

6 On the new building project see http://fgs-tempel.de/de/tempel-neubau. German language material includes, for instance, parts of the website, and a whole set of translation and transliteration of ritual texts for the daily use, FoGuang-Shan, Andachtsbuch (I). 


\section{Shaolin Tempel Deutschland}

The other famous example of a Chinese Buddhist institution in Berlin is the Shaolin Tempel Deutschland. Contrary to Fo Guang Shan Tempel Berlin, the establishment of the Shaolin Tempel Deutschland in 2001 did not solely rely on Chinese support. Much of their backing was provided by Germans who were mainly fond of Shaolin Martial Arts. ${ }^{7}$

After the first few years, the strengthened Shaolin Monastery 少 林寺 in China's Hebei Province sought to enrich the Shaolin Tempel Deutschland with a more religious dimension. The 'Sinicisation' of the Shaolin Tempel Deutschland led to many changes, especially of the personal structure of the centre. While the centre developed a more authentically religious functionality, new challenges arose for Germans whose passions depended on a more secular of Martial Arts.

Under its new Chinese leadership, the Shaolin Tempel Deutschland was going to invest in a huge urban project in order to broaden its influence in the German community. However, this initiative failed due to several reasons, one of which being the lack of support from the local German community. ${ }^{8}$ Nevertheless, the way Shaolin Monastery opened up to German practitioners of Shaolin Martial Arts in order to adapt to existing (local) partners and to bind them to its religious system is remarkable.

\section{Liuzu Tempel Deutschland}

Another relatively recent initiative in Germany goes back to the abbot of the Liuzu Monastery 六祖寺 in Southern China, Master Dayuan 大願 (b. 1971). He bought the building complex of the

7 See the homepage of the Shaolin Tempel Deutschland, https://www.shaolin-tempel.eu. The following information is based on the study by Lüdde, Die Akkulturation chinesisch-buddhistischer Kultur.

8 This project has been presented on the homepage for several years with an ongoing appeal for further support: https://www.shaolin-tempel.eu/projekt-tempelbau/. However, visionary projects are still being seen critically also in other parts of the world, see the report by Erling, 'Das Imperium des Kung-FuMönchs wackelt'. 
former Max Planck Institute for Solar System Research in the years 2015-2016 and led the official opening ceremony of the Liuzu Tempel Deutschland in June 2017. The aim was to make Chinese Buddhism attractive for Westerners by running a Chan meditation centre at the countryside that also offers other concepts represented by Master Dayuan, such as acupuncture-supported meditation practices, Theravada Buddhist meditation, and the Chinese lineage of tantric Medicine Buddha practices.

Although the local German government supported its initial phase of settlement, which aimed to stimulate the development of local business and culture after the removal of the Max Planck Institute, a large number of heavy difficulties regarding personal policy, visa applications, renovation, and language barriers led to a stagnation right from the beginning. Because of this, the institution has not yet offered any regular activities for a German audience. ${ }^{9}$

With regard to the above status, one of the main challenges of Chinese Buddhist institutions continues to be their ability to attract German groups. ${ }^{10}$ This is especially hard due to the cultural contexts mentioned previously in this analysis. So the question again arises concerning how far Germans have already formed their own view of Chinese Buddhism.

9 For basic information see the homepage of the Liuzu Monastery at https:// www.hrzh.org. On the initial phase see articles of local newspapers, such as Weiss, 'Max-Planck-Areal wird Meditationszentrum', and Hessische Niedersächsische Allgemeine, 'Mönche weihen Zentrum in Lindau ein'. Further background information is mainly based on visits to the Liuzu Tempel Deutschland in June 2017, February 2018 and to the Liuzu Monastery in January 2019.

10 Some initiatives of the distant and more recent past seem to have failed, so that they are not mentioned here in detail. One of the biggest movements of recent times, such as a Chinese Buddhist initiative in Frankfurt and other cities, with its European Centre in Utrecht and its Headquarters near Beijing, started an institutionalized spread in Germany in 2015, but never seems to have attracted a German audience (with the exception by some German language online services), and it seems to have declined since 2018, so that no Germany-related online material is accessible at the moment anymore. 


\section{II.2 General Image of Chinese Buddhism in Germany}

Independent from the former examples of institutionalized Chinese Buddhist centres, which would allow German insiders a much deeper insight into Chinese Buddhist life, the following section explores the issue of the general image of Chinese Buddhism in Germany as it is influenced by numerous other external factors. No scientific surveys have been conducted on this topic thus far. ${ }^{11}$ Therefore, the following examples stem from general impressions of Chinese Buddhism found within German society.

\section{'Chinese' Buddha: Fat Buddha-Laughing Buddha}

The most widely recognized figure in regards to Chinese Buddhism for a long time has been that of Mile 弥勒. Although this Chinese version of Maitreya can be found in the entrance of many Chinese restaurants in Germany, it is unlikely to produce a deeper understanding of Chinese Buddhism due to the general lack of understanding about the figure. Mile is referred to as the 'Fat Buddha' or 'Laughing Buddha' in many countries in the Western hemisphere. Therefore, the common comprehension of this Chinese version of Maitreya represents 'joy' instead of 'suffering' and its ridiculous appearance tends to connote 'superficiality' instead of Buddhist 'wisdom'.

This ambivalent and irritating image of the 'Fat/Laughing Buddha' went out of fashion in recent years, possibly because of the growing seriousness of Western interest in Buddhism and its closer connection with spiritual attributes like 'serenity' and 'meditation'. Although Buddha statues in a South East Asian style were most popular as decorative elements for a long time, in recent years the most

11 Although different kinds of books and recent studies on the image of China can be found, there is hardly any mention of Buddhism, see for example: Huawei-Studie 2016, Deutschland und China | Wabrnebmung und Realität; Thimm, China im Spiegel der deutschen Gesellschaft; Richter and Gebauer, Die China-Berichterstattung in den deutschen Medien; Pfeifer, Das Image Chinas in den deutschen Medien; Peng, Das Chinabild im deutschen öffentlich-rechtlichen Fernsehen. 
widely spread Buddha figure, apparent in public spaces, shops or private households, is reminiscent of an East Asian Buddhist art style. In contrast to the image of the 'Fat/Laughing Buddha', this newly popular style is more closely associated to the mainstream of Chinese Buddhist art and values, though its proximity to Chinese Buddhism has not found its way into public consciousness yet. ${ }^{12}$

\section{'Chinese'Sangha: Shaolin Martial Arts-Shaolin Kung Fu}

The most prominent image of a typical Chinese monk in the Western world is that of a kung fu master from the legendary Shaolin Monastery. He is impressive because of his combination of silence and impulsiveness in the same manner and mostly appears as a hero with supernatural powers. This hype surrounding Shaolin monks developed late in the 1960s and 1970s and was introduced chiefly by the film industry of Hong Kong and Hollywood. At that time, it did not matter that the Shaolin Monastery in Hebei Province had not yet been restored. ${ }^{13}$

The popularity of Shaolin monks was kept alive through 'Shaolin Shows'. These live performances attracted a German audience, regardless of whether the performers were real members of the Shaolin Monastery or not. ${ }^{14}$ After the Shaolin Monastery in China became more aware of the ambivalent image provoked by so many commercial activities, it tried to regain its sovereignty. A growing number of Germans were motivated by the search for authenticity

12 There is not much to be found about the attitude of Germans towards Buddha statues in public or private space, however remarkable may be the ironical commentary about recent tendencies by Martenstein, 'Über Buddhafiguren als Nachfolger des Gartenzwerges'. A more serious look into the future is given in Klein, 'Symbolik im Buddhismus'. About the early phase of Buddha statues in German households see a short summary in Repp, 'Eine Einführung in die Geschichte des Buddhismus in Deutschland', 13-14.

13 For an overview of history and growing international popularity of the Shaolin Monastery, see Shahar, The Shaolin Monastery.

14 See the study about martial arts shows from China by Wang-Scheerer, Shows aus China. 
and spirituality and tried to find out what was behind the myths of Shaolin. ${ }^{15}$ However, the typical image of a Chinese monk has not yet been separated from the stereotypical image of a Shaolin monk and changed into a more realistic view.

\section{'Chinese' Dharma: Chan-Teachings of Old Masters}

It is difficult to determine the common thoughts on Chinese Buddhist teachings in Germany. Most often, one comes across the famous Chinese Chan schools or a single master like Bodhidharma (fifth-sixth century) or Huineng 慧能 (638-713). These have not only influenced the Shaolin Martial Arts, but also can be regarded as the fundamental basis of many popular Japanese Zen schools. However, this context seems to push the Chinese Chan tradition back to function only as a secondary source. To a certain degree, Western audiences do not appear to take Chinese Chan Buddhism very seriously. On the one side, Chan teachings are considered to be far removed from the original teachings of the historical Buddha. On the other side, Chan Buddhism is viewed as not contemporary enough. In comparison, Japanese Zen Buddhism appears to be more mature and easier to experience in a lively manner. Pure Land traditions receive a similar impression of that ascribed to Chinese Buddhist teachings in general. Finally, the least known Buddhist teachings in Germany are those of contemporary masters from China. ${ }^{16}$ Because of this, the image of Chinese Buddhist teaching remains mainly characterized by a backward-looking attitude without concrete results.

15 Among the tendencies that slightly document a more serious approach, see: Schmidt, 'Ein Berliner will Shaolin-Mönch werden'; Kurz, Die Shaolin Mönche. As a climax of irritations about the authenticity of (Shaolin) monks in Germany, one may regard the critics of a report by SPIEGEL TV, see Engelbrecht, 'SPIEGEL TV Reportage. See also the recent critics by Erling, 'Das Imperium des Kung-Fu-Mönchs wackelt'.

16 The only exception is made by German translations of one or the other work of a very few famous monks such as.: Hsing Yun, Buddhas Weisheitsperlen; Sheng Yen, Fußspuren im Schnee; Jinghui, Die Tore des Chan-Buddhismus. 
On the contrary, Buddhist research by German scholars, which is well known worldwide, has contributed to the better understanding of Chinese Buddhist teachings in many respects. The image of Chinese Buddhism among German scholars is characterized by a very high acknowledgement for Chinese Buddhist teachings as independent from other Asian traditions. However, German scholars research thus far have primarily been concerned with historical topics, rather than investigating contemporary Chinese Buddhism. Therefore, this work has not contributed to developing a broader audience of German practitioners. ${ }^{17}$

\section{II.3 Possible Expectations from a German Audience}

The following section considers the potential factors for shaping more serious expectations of Germans towards Buddhism from China as a soteriological alternative to other religious systems. In analysing the current scenery of Buddhism in Germany, a major question concerns whether Chinese Buddhists will be able to convince the German public that they represent traditional lineages with links to authentic teachings in former periods of Chinese Buddhist history and to the historical Buddha himself.

This kind of expectation is closely connected with the common quest for a personal Buddhist master with charisma and a direct lineage. However, because Chinese Buddhism embodies a comprehensive religious system, Westerners expect it to be represented not only by a single master, but also by a community of monks (or nuns) as well as (Chinese) lay people.

Furthermore, we must consider the complicated question of German expectations of the actual Chinese Buddhist teachings themselves. Since the previous observations indicate a broad popularity of Japanese Zen Buddhism as well as of (the possible effects of)

17 As an example of the amount of translations of Chinese Buddhist texts by German scholars into Western languages, see Bingenheimer, Bibliography of Translations. Concerning the small influence on religious practice with regard to Chinese Buddhism, see Deeg, 'Buddhist Studies and its Impact'. 
Buddhist meditative practices, a significant role could be ascribed to the teachings of Chinese Chan Buddhism. In this context, possible expectations range from a confirmation of the Japanese Zen experience, to totally new (or unique) aspects of Buddhist teachings and practical methods which may serve as an alternative to Zen. Within the latter possibility, expectations for uniqueness may range from a journey back to the roots of historical Chan, to exclusive and innovative adaptations of Chan Buddhism to contemporary life.

What is further evident, especially considering the popularity of Tibetan Buddhism among Germans, is their previous expectation of profound ethical contents embedded in a systematized method of teaching on the basis of a fixed canon. Due to the lack of detailed knowledge about Chinese Buddhism, Germans may either expect it to be more demanding and rigorous (comparable with that of Japanese Zen Buddhism, Shaolin Martial Arts etc.), or as a more relaxed form of practice (as demonstrated by the 'Laughing Buddha'). Finally, each Buddhist tradition provides a framework of rituals, which may be more or less accepted among Germans according to each personal experience. ${ }^{18}$

\section{Institutional Context in China and the Ritual and Spiritual Contents to be Offered by Chinese Buddhists}

In relation to the above circumstances in Germany, it is also important to consider what the Chinese side is willing and able to transmit in the context of its internationalization. Buddhist life has been under harsh political pressure in the People's Republic of China for several decades. The processes of religious revival since the 1980s is ongoing and has an uncertain direction of its

18 On a mixture of expectations and surprises, how traditional as well as contemporary aspects of Chinese Buddhism can attract Westerners, see the German report of a journey of European Buddhists lead by Thich Nhath Hanh to Chinese Chan Buddhist monasteries in 1999, Litsch, 'Reise zu den Quellen des Chan-Buddhismus in China'. 
future development, especially since the sudden resignation of the President of the Buddhist Association of China in July 2018. Nevertheless, similar to the Japanese case several decades before, Buddhists in China nowadays enjoy quite a high degree of political acceptance and the economic development of China seems to allow an easier expansion within or outside the country than ever before. After most of the monasteries restored and even enlarged their compounds, and after they expanded their charity work outside of the monastery as far as it was tolerated by the government, ${ }^{19}$ their gradual expansion to foreign countries appeared as the next logical step. This international investment of Chinese religion may even be well received, because it pushes the soft power concept of the Chinese government's foreign policy and does not directly 'threaten' the Chinese government's domestic sovereignty. ${ }^{20}$ However, the extent of political freedom admitted by the Chinese government is not necessarily congruent with the extent of trust Westerners have in Chinese Buddhism. ${ }^{21}$

19 On the dynamics of social welfare by Buddhist organizations and its limitation within China during recent years, see: Ji, 'Chinese Buddhism as a Social Force'; Laliberté, 'Buddhist Revival under State Watch'; Laliberté, 'The growth of a Taiwanese Buddhist association in China'; Kuah-Pearce, 'Understanding suffering and giving compassion'.

20 See an overview of Chinese Buddhist soft power aspects in Angelskår, 'China's Buddhist Diplomacy'.

21 See for example, a sceptical commentary about the first World Buddhist Forum 2006, von Hein, 'Kommentar: Opium fürs Volk?'. A similar sceptical attitude has been shown during recent years in international analysis (although not yet so much debated in German media), since Chinese Buddhists increasingly participate in the Chinese government's soft power policy in Southeast Asia, see: Overdorf, 'China vs. India: the battle for Buddha'; Stobdan, 'To Deploy the Soft Power of Buddhism, India Needs to Embrace the Sangha'; Scott, 'Buddhism in Current China-India Diplomacy'. The case of the Longquan-Monastery's abbot which has become the most politically sensitive case of the recent past, however, has much more been perceived in Germany as part of the MeToo phenomenon, see Deutsche Welle, 'Ein Abt und “\#MeToo"'. 
The Chinese government's willingness to introduce Buddhism outside of China is based on a growing self-consciousness and relatively positive experiences with the support of Buddhist life among overseas Chinese in South East Asian and other (Non-European) countries. In recent years, a growing number of monasteries from China are presenting themselves in European countries (including Germany). However, this is a relatively new movement and at the current stage it appears to be a testing phase without a concrete direction. ${ }^{22}$

While singular Chinese Buddhist events seem to attract Germans in a positive manner, especially when they are focused on traditional aspects, there is a certain reluctance among Germans towards bigger events with more modernized elements. These events appear more commercial, less authentic and maybe even too visionary and overwhelming. ${ }^{23}$

Since most of the abbots of Chinese monasteries belong to the new generation born during the 1970s, their ability to achieve a sufficient authoritative image in a foreign context is called into question, even if they have success within China. However, the historical background of their monastery or a reference to the genealogy of their personal Buddhist master(s), if those are internationally well-known enough, could help these masters to gain international respect. Still, it remains a big challenge for this generation to act abroad, especially since they have little experience with foreign language and culture.

The predominant Buddhist teachings in Chinese monasteries today are far from being homogenous. This includes the case of Chan Buddhist teachings and practices (which may be of a special interest for Germans as mentioned above) that have experienced a notable re-

22 For example, according to personal observations, there have been visits to Germany and other European countries during the very recent years by delegations of the Lingyin Monastery, Daxiangguo Monastery, Liuzu Monastery, Longquan Monastery etc., looking for ways of expansion in a different manner and with varying results.

23 This may range from a sceptical attitude towards entertainment shows to investment plans for nationwide Buddhist centres. 
vival in recent years with a heterogeneous output. ${ }^{24}$ At the same time, there are numerous influences of other Buddhist schools (not only of the Pure Land tradition) involved in the revival process in China. These are based on various old texts which have not been translated into foreign languages but with new texts and doctrines added by contemporary masters. Although such a dynamic mixture of influences is nothing new in Chinese Buddhist history, as well as in Buddhist history in general, it will not be easy for Chinese Buddhists to make foreigners understand what belongs to which tradition (or innovation) and to convince them of the specific system of their individual monastery. However, it is this rich treasury of unknown (or newly inspired and systematized) Buddhist thinking which also has the potential to attract an international community if one takes the time to transfer it in a distinguished and reflected manner. A crucial point of question may be whether the concept of Renjian Fojiao (mostly translated as 'Humanistic Buddhism'), which is not only perpetuated by FGS, but has roots in the reform movements of the early twentieth century, has the potential to serve as a tool for making Chinese Buddhism more internationally adaptable and acceptable. ${ }^{25}$ The ongoing debate in Mainland China among Buddhists and scholars of Buddhist Studies, which came up during a conference in 2016, however, reveals a lot of internal doctrinal discrepancies. ${ }^{26}$

In contrast to that, the ritual setting of Chinese Buddhism, which forms the basis for the common practice of a Buddhist community, is far more standardized than the heterogeneous teachings mentioned above. Considering a transformation of those rituals to Germany, many difficulties can be expected, as seen in the transmission of

24 See about the variety of contemporary phenomena in Nichols, 'Typologizing Religious Practice at Buddhist Monasteries in Contemporary China'.

25 See possible arguments for it in the article of Travagnin, 'Genealogy and Taxonomy'.

26 On a new controversial debate about Renjian Fojiao, there was a documentation of the 2016 conference's organizers at their website www.fojiaoyixue.org until early 2019, also see reactions, for instance, in the journals Hongshi 弘誓 $(2017,2018)$ and Fayin xuebao 法印學報 (2017). 
Buddhist traditions from other countries. Transmission could be especially difficult if the Chinese side is not flexible enough to adapt its system to the Western cultural context. The possible problems include anything from the (hierarchical) relations between master and disciple and between men and women, up to conflicts regarding the donation system, funeral rituals etc. Seeing as though an integral part of Chinese Buddhist rituals is chanting and reciting texts and mantras, which are extremely hard to learn for foreigners, it is this aspect which may pose one of the biggest obstacles for integrating foreigners into an existing Chinese speaking community. On the contrary, experiencing a new musical and spiritual level could also potentially attract an international community, once again if one takes the time to adapt it in a distinguished and reflected manner. ${ }^{27}$

\section{Preliminary Conclusion of the Largest Challenges and Opportunities for Potential Adaptation and Growing Acceptance of Chinese Buddhism in Europe}

As can be seen from the preliminary analysis above, the first complication for Chinese Buddhism in its transmission to Germany was its lack of roots, aside from a few and special (semi-successful) cases. There already exists a lively Buddhist community in Germany inspired by traditions from many other countries which gradually developed by local characteristics. However, the preceding presence of Buddhism also provides an opportunity for Chinese Buddhism if Germans and Chinese open up their mind to new inter-cultural encounters.

The pre-existing image of Chinese Buddhism among Germans also presents a challenge for Chinese to cope with, because it reveals a low level of knowledge about Chinese Buddhist culture. Despite this, many existing prejudices imply a positive connotation. Therefore, it can also be used as an opportunity for Chinese Buddhists to trans-

\footnotetext{
27 These questions are worth to be studied with a focus on Chinese Buddhism in addition to the above mentioned research project report by Prohl, Projektbericht zum DFG-Projekt'.
} 
form these views and provide additional background information to construct a broader and deeper understanding of Chinese Buddhism.

One of the biggest challenges that Chinese Buddhism must face is finding a balance between the possible expectations among Germans and the concerns about what Chinese Buddhists can offer them. The most challenging expectations of Germans may range from a political level regarding the institutional framing ('independence of political influence') to spiritual questions of authenticity ('back to the roots of Chan Buddhism') and innovation ('refreshing new generation of Buddhist masters'), as well as ritual concerns ('reluctant attitude towards culturally influenced habits'). In general, Chinese Buddhists may be able to comply with these expectations. However, due to historical and political circumstances, Chinese Buddhism needs time to adapt and develop the openness to accommodate these expectations. In this respect, one can see an abundance of opportunities for Chinese Buddhists in Germany, if they continue to learn from their experiences with other countries and from the experiences of other Buddhist traditions that already developed a longer history of transmission to Germany.

Another way of transmitting Chinese Buddhism in the future may be represented by German native speakers. However, the success of situations such as a German lay organization based in Villingen-Schwenningen near Stuttgart without a Chinese speaking connection, or a single German nun's initiative in Berlin based on extensive personal experience in Buddhist Monasteries in Taiwan without an institutional connection, ${ }^{28}$ remains to be seen in further development.

28 On the German lay organisation 'Bodhidharma Chan Gemeinschaft' which was founded in 2014 as a member of the Zen Buddhist Order of Hsu Yun (ZBOHY) see https://www.bodhidharma-chan-gemeinschaft.de. It gives the explanation: 'Formally, in the sense of a lineage, we are in the Chinese Linji-tradition (臨濟宗) in succession to the Buddha, Bodhidharma, Huang Po, Xu Yun, Jy Din Shakya and in the west of Chuan Zhi and Fa Dao. [...] From the secular point of view of our science-based teacher, the way of the Chan is completely timeless and not bound to any culture or language.' The German nun's initiative in Berlin has been founded in 2018 under the name 'Miao Fa Zentrum für Meditation und Chan Buddhismus', see http://www.miao-fa.de. 


\section{Bibliography}

Angelskår, Trine. 'China’s Buddhist Diplomacy'. Norwegian

Peacebuilding Resource Centre Report, March 2013.

Baumann, Martin. 'Buddhism in Europe: Past, Present, Prospects'.

In Westwards Dharma: Buddhism Beyond Asia, edited by

Charles S. Prebish and Martin Baumann, 85-105. Berkeley:

University of California Press, 2002.

- _ - 'Global Buddhism: Developmental Periods, Regional

Histories, and a New Analytical Perspective'. Journal of Global

Buddhism 2 (2001): 1-43.

- - Deutsche Buddhisten: Geschichte und Gemeinschaften

[German Buddhists: History and Associations], 2nd enlarged ed. Marburg: Diagonal, 1993.

Bingenheimer, Marcus. Bibliography of Translations from the Chinese

Buddhist Canon into Western Languages. Updated in 2019.

http://mbingenheimer.net/tools/bibls/transbibl.html.

Chandler, Stuart. Establishing a Pure Land on Earth: The Foguang

Buddhist Perspective on Modernization and Globalization.

Honolulu: University of Hawaii Press, 2004.

Deeg, Max. 'Buddhist Studies and its Impact on Buddhism in

Western Societies. An Historical Sketch and Prospects'.

Purify Mind, 2002. http://www.purifymind.com/

BuddhismWestSociety.htm.

Deutsche Welle. 'Ein Abt und "\#MeToo" in China' [An Abbot and

\#MeToo in China]. August 2, 2018. https://www.dw.com/de/

ein-abt-und-metoo-in-china/a-44924367.

Engelbrecht, T. 'SPIEGEL TV Reportage "Kämpfen für Buddha"

macht irreführende Werbung für einen falschen Shaolin-Tempel, in dem der Abt kein Abt und die Meister keine Meister sind' [SPIEGEL TV Report "Fighting for the Buddha” Misleadingly Advertises a False Shaolin Temple in Which the Abbot is no Abbot and the Masters are no Masters]. spiegelblog.net, February 2, 2012. http://www.spiegelblog.net/spiegel-tv-reportagekaempfen-fuer-buddha.html.

Erling, Johnny. 'Das Imperium des Kung-Fu-Mönchs wackelt' [The Kung Fu Monk's Empire is Reeling]. WELT, August 9, 2015. 
https://www.welt.de/politik/ausland/article144996379/DasImperium-des-Kung-Fu-Moenchs-wackelt.html.

Fo-Guang-Shan 佛光山, ed. Andachtsbuch (I) [Book of Devotion]. Berlin: Fo Guang Shan Tempel, 2006.

Günzel, Marcus. Die Taiwan-Erfahrung des chinesischen Sangha. Zur Entwicklung des buddhistischen Mönchs-und Nonnenordens in der Republik China nach 1949 [The Chinese Sangha's Taiwan Experience. On the Development of the Buddhist Order of Monks and Nuns in the Republic of China After 1949]. Göttingen: Seminar für Indologie und Buddhismuskunde, 1998. Richter, Carola, and Sebastian Gebauer. Die China-Berichterstattung in den deutschen Medien [Reports on China in German Media]. Berlin: Heinrich-Böll-Stiftung, 2010.

Hessische Niedersächsische Allgemeine. 'Mönche weihen Zentrum in Lindau ein' [Monks Consecrate Center in Lindau]. June 28, 2017. https://www.hna.de/lokales/northeim/katlenburg-lindauort306070/moenche-weihen-zentrum-in-lindau-ein-8439437. html.

Hsing Yun 星雲. Buddhas Weisheitsperlen [Buddha's Pearls of Wisdom]. Translated by Claudia Stevens. Darmstadt: Schirner, 2003.

Huawei-Studie 2016. Deutschland und China | Wabrnebmung und Realität [Germany and China. Perception and Reality]. Berlin: Druckteam Berlin, 2016.

Ji Zhe. 'Chinese Buddhism as a Social Force. Reality and Potential of Thirty Years of Revival'. Chinese Sociological Review 45, no. 2 Winter (2013): 8-26.

Jing Hui 净慧. Die Tore des Chan-Buddhismus [The Way of Chan Buddhism]. Bielefeld: Theseus Verlag, 2010.

Klein, Mechthild. 'Symbolik im Buddhismus. Was Buddhas große Ohren, sein Haardutt und seine Gestik bedeuten' [Buddhist Symbolism. What Buddha's Large Ears, His Hair Bun, and His Gestures Mean]. Deutschlandradio Kultur [Germany radio culture], May 22, 2016. https://www.deutschlandradiokultur.de/ symbolik-im-buddhismus-was-buddhas-grosse-ohren-sein.1278. de.html?dram:article_id=354815.

Kuah-Pearce, Khun Eng. 'Understanding suffering and giving 
compassion: the reach of socially engaged Buddhism into China'. Anthropology $\sigma^{2}$ Medicine 21, no. 1 (2014): 27-42.

Kurz, Felix. Die Shaolin Mönche [Shaolin Monks]. Berlin: Braus, 2012.

Laliberté, André. 'Buddhist Revival under State Watch'. Journal of Current Chinese Affairs 40, no. 2 (2011): 107-34.

- - - ' 'The growth of a Taiwanese Buddhist association in China: Soft power and institutional learning'. China Information 27, no. 1 (2012): 81-105.

Litsch, Franz-Johannes. 'Reise zu den Quellen des ChanBuddhismus in China' [Voyage to the Sources of Chan Buddhism in China]. Netzwerk engagierter Buddhisten [Network of Engaged Buddhists], 1999. http://www.buddhanetz.org/ aktuell/chan.htm.

Lüdde, Johanna. Die Akkulturation chinesisch-buddhistischer Kultur im 'Shaolin Tempel Deutschland' [The Acculturation of Chinese Buddhist Culture in the Shaolin Temple Germany]. Berlin: LIT Verlag, 2007.

- - - 'Die Akkulturation des Chan-Buddhismus im Shaolin Tempel Deutschland' [The Acculturation of Chan Buddhism in Shaolin Temple Germany]. Transformierte Buddhismen [Buddhisms Transformed] 2 (January 2008): 28-53.

Martenstein, Harald. 'Über Buddhafiguren als Nachfolger des Gartenzwerges' [On Buddha Statues as Successors of the Garden Gnome]. ZEITmagazin 20 (2013). https://www.zeit. de/2013/20/harald-martenstein.

Nichols, Brian J. 'Typologizing Religious Practice at Buddhist Monasteries in Contemporary China'. In 'Han cbuan Fojiao yanjiu de guoqu xianzai weilai buiyi lunwen ji 《漢傳佛教研究的 過去現在未來》會議論文集 [Conference Proceedings of 'Chinese Buddhism: Past, Present and Future'], 411-36. Foguang daxue fojiao yanjiu zhongxin 佛光大學佛教研究中心 [Fo Guang University Buddhist Research Centre], April 2015.

Overdorf, Jason. 'China vs. India: the battle for Buddha'. Global Post, February 19, 2012. https://www.pri.org/stories/2012-01-19/ china-vs-india-battle-buddha.

Peng Kuang. Das Chinabild im deutschen öffentlich-rechtlichen 
Fernsehen: Eine Inhaltsanalyse am Beispiel der China-

Berichterstattung des ZDF im Jabr 2008 [The Image of China in German Public Television. A Content Analysis of ZDF Reports on China in 2008]. Marburg: Tectum Verlag Marburg, 2014.

Pfeifer, Susanne. Das Image Chinas in den deutschen Medien. Eine Inhaltsanalyse ausgewäblter überregionaler deutscher Tageszeitungen im Kontext der Vorbereitung und Austragung der Olympischen Spiele 2008 [The Image of China in German Media. A Content Analysis of Transregional German Newspapers in the Context of the Preparation of the Olympic Games and their Events]. Saarbrücken: Vdm Verlag Dr. Müller, 2009.

Prohl, Inken. 'Projektbericht zum DFG-Projekt "SinnsucheCoping-Streben nach Wohlgefühl”. Transformationen buddhistisch inspirierter Vorstellungen und Praktiken in der deutschen Gegenwartsgesellschaft' [Report on the DFG (German Science Council) Project 'Search for Meaning'Coping-Pursuit of Well-Being. Transformations of Ideas and Practices Inspired by Buddhism in Contemporary German Society]. Ruprecht-Karls-Universität Heidelberg, June 1, 2007. http://www.zegk.uni-heidelberg.de/religionswissenschaft/ forschung/buddhismus-deutschland/Projektbericht_ Transformationen_des_Buddhismus_062007.pdf.

Repp, Martin. 'Eine Einführung in die Geschichte des Buddhismus in Deutschland' [An Introduction to the History of Buddhism in Germany]. Zentrum Ökumene der Evangelischen Kirche in Hessen und Nassau und der Evangelischen Kirche von KurbessenWaldeck [Ecumenical Centre of the Evangelical Church in Hessen and Nassau and the Evangelical Church of KurhessenWaldeck], February 2010. http://www.zentrum-oekumene. de/fileadmin/content/Materialien/Dokumentationen/Gesch. Dt.Buddh.Essay.pdf.

Schmidt, Miriam. 'Ein Berliner will Shaolin-Mönch werden' [A Person from Berlin Wants to Become a Shaolin Monk]. Badische Zeitung, August 31, 2012. https://www.badischezeitung.de/deutschland-1/ein-berliner-will-shaolin-moenchwerden--63023911.html.

Scott, David. 'Buddhism in Current China-India Diplomacy'. 
Journal of Current Chinese Affairs 45, no. 3 (2016): 139-74. Shahar, Meir. The Shaolin Monastery: History, Religion, and the Chinese Martial Arts. Honolulu: University of Hawai'i Press, 2008.

Sheng Yen 聖嚴. Fußspuren im Schnee: Autobiografie eines buddhistischen Mönchs aus China [Footprints in the Snow: An Autobiography of a Buddhist Monk from China]. Translated by Susanne Schaup. Bielefeld: Theseus Verlag, 2010.

Stobdan, Phunchok. 'To Deploy the Soft Power of Buddhism, India Needs to Embrace the Sangha'. The Wire, November 29, 2016. https://thewire.in/83060/buddhism-soft-power-india-china/. Thimm, Caja. China im Spiegel der deutschen Gesellschaft: Images, Einstellungen und Erwartungen in Wirtschaft, Wissenschaft und Kultur [China as Mirrored in German Society. Images, Attitudes, and Expectations in Economy, the Sciences, and Culture]. Bonn: Bonner Akademie für Forschung und Lehre praktischer Politik (BAPP), 2014.

Travagnin, Stefania. 'Genealogy and Taxonomy of the "Twentiethcentury Renjian Fojiao 人間佛教”: Mapping a famen 法門 from Mainland China and Taiwan to Europe'. Renjian Fojiao xuebao 人間佛教學報 9 (May 2017), 180-97.

von Hein, Matthias. 'Kommentar: Opium fürs Volk?' [Commentary: The Opium of the People?]. Deutsche Welle online, April 13, 2006. https://www.dw.com/de/kommentar-opium-f\%C3\%BCrsvolk/a-1968619.

Wang-Scheerer, Liyuan. Shows aus China. Beitrag zur transkulturellen Kommunikation. Am Beispiel des Chinesischen Staatszirkus und der Shaolin-Kampfkunstmönche [Shows from China. A Contribution to Transcultural Communication. The Example of the Chinese State Circus and the Shaolin Martial Arts Monks]. Münster: LIT Verlag, 2007.

Weiss, Olaf. 'Lindau: Max-Planck-Areal wird Meditationszentrum' [Lindau: The Area of (a former) Max Planck (Institute) is Turned into a Center of Meditation]. Hessische Niedersächsische Allgemeine [Hessian Lower Saxony General], April 3, 2017. https://www.hna.de/lokales/northeim/lindau-ort28988/lindaumax-planck-areal-wird-meditationszentrum-8077411.html. 